\title{
Remote Peer Review: Readiness, Efficacy, and Challenges
}

\section{Shoko Kita \\ Rikkyo University}

\section{Reference Data}

Kita, S. (2021). Remote peer review: Readiness, efficacy, and challenges. In P. Clements, R. Derrah, \& P. Ferguson (Eds.), Communities of teachers \& learners. JALT. https://doi.org/10.37546/ JALTPCP2020-45

A growing body of research has reported on the positive effects of student peer review. While those studies highlight collaboration among learners as a prerequisite for successful peer review, those studies highlight collaboration among learners as a prerequisite for successful peer review,
due to the spread of COVID-19 in 2020, the 1st-year university students in this study went through an unusual rapport-building process. This meant students peer-reviewed online for their reading and writing class without any chance to meet their classmates face-to-face. The current study used an online survey followed by interviews to explore those learners' experiences participating in online peer reviews using Google Docs. The results showed that even though the participants faced some challenges, such as online communication difficulties, the majority of them found the online peer review beneficial to improve their writing and reading skills. Participating in a followup online discussion, after providing written peer feedback, was also perceived to be helpful for rapport building and negotiating meaning regarding feedback.

ピアレビューの有効性は先行研究により報告されており、学習者同士の協力が効果的なピアレビューの基盤となるという 報告もある。しかし、2020年の新型コロナウイルス感染拡大により、本研究のリーディング・ライティングクラスの大学一年生 は、対面でのコミュニケーションを一度も図らずにクラスメイトとラポートを築きながら、グーグルドキュメントを使用したピア レビューを行うこととなった。このような、従来とは異なる状況下でのピアレビューの学習体験について質的調査を行うため、 オンラインによるアンケートとインタビューを行った。コミュニケーションの問題等も報告されたが、多数の被験者が、オンラ メントに加えて、その後に行ったペアやグループでのコメントに関するディスカッションが有効であることが示唆された。

tudent peer review is considered an essential part of the process approach to EFL/ESL $\checkmark$ writing for several reasons. For example, peer reviews enable learners to reflect on the strengths and weaknesses of their writing, promote their awareness of the audience (Tsui \& Ng, 2000), and facilitate improved revisions (Early \& Saidy, 2014). To make peer reviews successful, collaboration among learners plays an important role because it helps learners to negotiate meaning and reflect on their writing (Lockhart \& $\mathrm{Ng}, 1995)$. In contrast, a lack of collaboration may discourage learners from incorporating their peer's feedback into their writing (Nelson \& Murphy, 1993).

Although collaboration is essential for successful student peer reviews, establishing a sense of community can be challenging online (Song et al., 2004). The difficulty with building a sense of community in an online environment became even more problematic in 2020 when many university students were forced to take classes online due to the spread of COVID-19. As a result, participants in the current study needed to build rapport in an unusual manner, without being able to meet their classmates in person. This study aims to gain a better understanding of online learners' readiness to participate in peer review under these unexpected circumstances, as well as to examine the effectiveness and challenges of online peer review activities under these conditions.

\section{Literature Review}

More university teachers have been incorporating computer-mediated peer reviews in their writing classes as a result of advances in technology (Guardado \& Shi, 2007). Studies regarding the effectiveness of these technology-based peer reviews in high school and university have presented mixed results. Some research demonstrates the positive effects of online peer reviews. For example, Loretto et al. (2016) conducted a quantitative and qualitative study where 513 high school students used an online peer review system called $S W o R D$, which anonymously and randomly assigned their writing to multiple reviewers. The results of the study showed that by streamlining the grouping process, an online system can make it easier for the high school students to receive feedback from multiple reviewers. The researchers also reported that the students appreciated the anonymity of online peer review because it helped reduce the discomfort 
associated with exchanging critical feedback, which increased the amount of honest feedback the students gave. Liu and Sadler (2003) also reported that their technologybased group of university students tended to provide more revision-oriented comments, especially on local issues, when they exchanged written feedback using Microsoft Word asynchronously. In contrast, the traditional face-to-face group tended to provide nonrevision-oriented evaluative feedback, such as comments like "really nice introduction" (p. 206), when they asynchronously exchanged written feedback on their papers. In addition, Wang and Usaha (2009) compared the quality of the writings of a face-to-face group and an online group of university students. The face-to-face group exchanged oral and written feedback in the classroom while the online group asynchronously exchanged written feedback using Moodle's Forums. They found that the online peer review resulted in higher quality essays than the more traditional peer-review process.

Although online peer reviews have been shown to have positive effects, there are also potential drawbacks. For example, learners may have difficulty selecting appropriate feedback when receiving inconsistent suggestions from multiple reviewers (Loretto et al., 2016). Online peer reviews can also be challenging when learners do not have a chance to meet their classmates in person. Zhao et al. (2014) explored university students' experiences with peer reviewing in a distance education course where they discussed their writings in an online forum. These researchers concluded that to be able to collaborate effectively in this environment, students need scaffolding that promotes interaction and social presence. Finally, the most critical drawback of online peer review is that it may lead to a lack of communication among learners. According to Chang (2012), learners tended to rely more on their own interpretation when providing feedback instead of clarifying meaning with their peers in an asynchronous online environment. Liu and Sadler (2003) also reported that their participants tended to go offtopic and make less use of nonverbal communication when they discussed their feedback synchronously in an online chat room. These resulted in less effective peer-review, where learners spent more time on conversation maintenance than discussing revisions. Considering those difficulties, some researchers recommend combining online written feedback with follow-up face-to-face discussions to maximize the effectiveness of online peer reviews (e.g., Ho \& Savignon, 2007; Li \& Li, 2018; Liu \& Sadler, 2003).

One of the biggest differences between the current study and the studies reviewed above is that those studies were conducted before the pandemic. The majority of these studies were conducted in face-to-face high school or university contexts, which meant that the learners probably had a chance to meet and communicate with their classmates in person before they participated in the online peer review activities. In contrast, in this study, due to the emergent COVID-19 situation, the participants did not have a similar opportunity to communicate with their peers in person before doing peer review. To explore the participants' online peer review experiences under these unexpected circumstances, the current study investigates students' perceptions of the online peer review activities they did as part of their first-year university reading and writing class. The study focuses on the students' perception because learners' perceptions can impact their motivation towards learning as well as the success of classroom activities (Loretto et al., 2016). To investigate the participants' experiences, I explored these three research questions:

RQ1. To what extent did remote learning impact the participants' perception of their readiness to exchange feedback with their classmates?

RQ2. What challenges did the participants experience when they took part in the online peer review activities?

RQ3. To what extent did the participants find online peer review activities effective?

\section{Context and Participants}

This study was conducted in a mandatory reading and writing class (hereafter R\&W) for 1st-year students at a private university in Tokyo. Each class lasted for 100 minutes, and the students met weekly over the course of 12 weeks. In this course, the students read three graded readers of their choice and wrote book reports. After writing each report, they participated in online peer review.

Nineteen 1st-year students participated in this qualitative study voluntarily. Their TOEIC Listening \& Reading test scores were between 480 and 679 . Only five of these participants had taken online classes, and only one of them had used Google Docs before taking this course. None of them knew their classmates before the semester began. All participants gave informed consent to participate in the study, and the university's institutional review board cleared the project prior to commencing with the research.

\section{Peer Review Procedure}

The participants followed a structured procedure for doing the online peer reviews. Before the first peer review, they received an approximately 40-minute training session that covered the rationale for peer review, guidelines about providing constructive feedback with more focus on global issues than local issues, as well as instructions about how to use Google Docs. This step was to ensure that the participants received 
training in the peer review process, which has been found to be a key factor for successful peer reviews (Min, 2006). At first, the participants read a chapter about collaborative learning in their textbook, Select Readings by Lee and Gundersen (2011), after which they discussed collaborative learning. Then I explained the three steps of the peer review process and their purposes: (1) understanding the content, (2) commenting on global issues, and (3) commenting on local issues. I also provided guiding questions and expressions to exchange constructive feedback (e.g., One thing I like about your report is $\mathrm{X}$ ), and then demonstrated how to comment on Google Docs by providing example comments on a student's book report.

Following the training, the participants used the three-step peer-review process described above to provide feedback on a few classmates' book reports. Following the findings of Moloudi (2011), I read their reports in advance and paired off participants who were at a similar writing proficiency level. While the participants exchanged comments, I monitored the peer review process and commented on their feedback concurrently using the comment feature of Google Docs. After exchanging written feedback, the participants discussed and clarified their comments in breakout rooms on Zoom, after which they revised their reports.

\section{Data Collection and Analysis}

To investigate the participants' perception regarding their readiness for, the efficacy of, and the challenges of the online peer review process, I conducted a Google Forms survey in the final lesson. The survey included 24 questions written in both English and Japanese including Likert-scale questions, multiple response questions, and open-ended questions (see Appendix A). After the survey, four participants voluntarily participated in separate interviews to share their experiences in more detail. Two of the interviews were conducted on Zoom in Japanese for approximately 15 minutes each, while the other two were conducted in written form via email. Seven questions were prepared for the interviews (see Appendix B), and follow-up questions were asked based on the participant's answers.

After collecting the data, I transcribed the Zoom interview sessions and translated the Japanese comments from both the open-ended questions and the interviews into English. The participants' responses to the open-ended survey and interview questions were input into a Microsoft Excel sheet and analyzed following the coding cycle outlined by Saldaña (2013). At the first coding stage, I used Saldaña’s (2013) descriptive coding technique by adding a word or phrases that summarized the topic of the comments, such as spending time with classmates. Then I used code mapping at the second coding stage, where I reorganized the comments into categories until major themes, such as rapport building, emerged.

\section{Readiness}

\section{Results}

Regarding the first research question, remote learning did not seem to have a major negative impact on the participants' readiness to participate in the online peer review. Most of the participants reported being comfortable with the online peer review activities from the beginning, and their comfort level further increased mainly through rapport-building with their classmates and learning about the peer review process.

The participants' responses to a Likert-scale question, I felt worried about taking classes online before the semester, show that 18 of the 19 participants (95\%) had concerns about taking classes online before the semester started (see Table 1). However, despite the concerns expressed about online classes, their responses to another Likert-scale question, $I$ was comfortable participating in peer review activities using Google Docs from the beginning, showed that 15 of the 19 participants (79\%) felt comfortable participating in the online peer review from the beginning. Moreover, 18 of the 19 participants (95\%) indicated that they became even more comfortable with the online peer review as the semester progressed.

Table 1

Participants' Answers Regarding Their Readiness

\begin{tabular}{lcccccc}
\hline & $\begin{array}{l}\text { Strongly } \\
\text { disagree }\end{array}$ & Disagree & $\begin{array}{c}\text { Slightly } \\
\text { disagree }\end{array}$ & $\begin{array}{c}\text { Slightly } \\
\text { Agree }\end{array}$ & $\begin{array}{c}\text { Agree } \\
\text { Strongly } \\
\text { agree }\end{array}$ \\
\hline $\begin{array}{l}\text { Q1: I felt worried about } \\
\text { taking classes online before } \\
\text { the semester }\end{array}$ & 0 & 0 & 1 & 1 & 7 & 10 \\
$\begin{array}{l}\text { Q2: I was comfortable } \\
\text { participating in peer review }\end{array}$ & 0 & 1 & 3 & 2 & 10 & 3 \\
$\begin{array}{l}\text { activities using Google Docs } \\
\text { from the beginning }\end{array}$ & & $(5 \%)$ & $(16 \%)$ & $(11 \%)$ & $(53 \%)$ & $(16 \%)$ \\
$\begin{array}{l}\text { Q3: I became more } \\
\text { comfortable participating in } \\
\text { peer review activities using } \\
\begin{array}{l}\text { Google Docs as the semester } \\
\text { went on }\end{array}\end{array}$ & 0 & 0 & 1 & 3 & 10 & 5 \\
\hline
\end{tabular}

Note. $\mathrm{N}=19$. 
In the survey, the participants also selected the factors they felt increased their comfort level towards online peer reviews. Three of the four most frequently selected items shared a common theme of rapport building with classmates (see Table 2). The item that resonated the most with the participants was seeing each other in the online $R \& W$ class every week, selected by 12 out of 19 participants. From these results, we can ascertain that spending time with classmates online during the $\mathrm{R} \& \mathrm{~W}$ classes may have allowed them to participate more easily in the online peer review, even though they were not able to meet in person. This view was endorsed by three of the four interviewees' comments. One of them provided the following response:

At first, I was quite hesitant because we didn't know each other at all, and we weren't able to see each other in person due to the online classes. However, by talking to them in the breakout rooms [on Zoom], I started to be able to give suggestions, for example, "This may be more concise."

Together this shows that while providing critical feedback may have been challenging at first, after communicating with their classmates online, the participants became comfortable enough to begin offering revision-oriented feedback.

Table 2

Factors Contributing to Increased Comfort Level Towards Online Peer Review

\section{Factors}

Number of

Seeing each other in the online R\&W class every week participants

Taking other English classes with the classmates

$12(63 \%)$

Talking to the classmates in pairs and groups in Zoom breakout rooms

$11(58 \%)$ in the $\mathrm{R} \& \mathrm{~W}$ class

Seeing my classmates' comments

Seeing how the instructor gave sample comments before the peer review

Receiving instructions on how to give comments on Google Docs

Practicing giving comments throughout the semester

$11(58 \%)$

Having classmates who made me feel comfortable

$9(47 \%)$

$8(42 \%)$

$7(37 \%)$

$6(32 \%)$

Taking other non-English classes together online

\begin{tabular}{lc}
\hline Factors & $\begin{array}{c}\text { Number of } \\
\text { participants }\end{array}$ \\
\hline Communicating with my classmates outside the class & $2(11 \%)$ \\
Feeling confident about my English skills & $2(11 \%)$ \\
Feeling confident about my feedback points & $2(11 \%)$ \\
$\begin{array}{l}\text { Other: Receiving affirmative comments from the instructor on the first } \\
\text { comment I nervously wrote }\end{array}$ & $1(5 \%)$
\end{tabular}

Note. $\mathrm{N}=19$.

Another item related to rapport building, talking to the classmates in pairs and groups in Zoom breakout rooms in $R \& W$ class, was selected by 11 of the 19 participants. While these responses can be seen to also highlight the importance of rapport building, two of the four interviewees' comments presented another possible reason for these responses. One interviewee provided the following comment, "We had time to discuss our comments. It was easier to make ourselves understood by actually talking. When I didn't understand, I could ask questions before revising. Seeing the classmates' faces and hearing their voice was important." From this comment, it is possible to see that the follow-up discussions on Zoom were perceived as an effective way to negotiate meaning about their written comments.

The interviewee's comment that "seeing the classmates' faces was important" is interesting because it contradicts prior research that recommends anonymous online peer review (e.g., Loretto et al., 2016). This is supported by another interviewee who stated:

Because of online classes, we had fewer opportunities to communicate with classmates, so seeing their faces and knowing who gave comments helped us get to know each other. I liked that the peer review was not anonymous for the purpose of making friends.

When learners do not have the option to communicate with their classmates in person, some learners may prefer non-anonymous peer reviews, which can help them build rapport with their classmates and negotiate meaning regarding their feedback more effectively.

The second most common theme that emerged was the importance of learning about how to conduct peer review. Those items included learning from their peers, such as 
seeing my classmates' comments chosen by 11 of the 19 participants as well as learning from the instructor, such as seeing how the instructor gave sample comments before the peer review selected by nine participants. Finally, the items that were selected the least were related to communicating with their classmates outside the English classes and having confidence in their skills. These challenges will be discussed in more detail in the next section.

\section{Challenges}

Regarding the second research question, although many participants felt comfortable with the online peer review, some participants still faced challenges, including insufficient rapport-building opportunities, their perceived lack of skills, technical problems, and communication issues.

The participants' responses to the following two Likert scale questions were analyzed to explore their experiences: (1) Peer review activities using Google Docs were difficult and (2) If I had taken this class face-to-face, it would have been easier to participate in peer review activities. The data regarding the first question showed that eight of the 19 participants (42\%) found the online peer review challenging. In addition, 17 of the 19 participants $(90 \%)$ agreed that face-to-face peer review would have been easier for them than the online version (see Table 3 ).

Table 3

Participant Answers to Questions Regarding Challenges

\begin{tabular}{|c|c|c|c|c|c|c|}
\hline & $\begin{array}{l}\text { Strongly } \\
\text { disagree }\end{array}$ & Disagree & $\begin{array}{l}\text { Slightly } \\
\text { disagree }\end{array}$ & $\begin{array}{c}\text { Slightly } \\
\text { Agree }\end{array}$ & Agree & $\begin{array}{c}\text { Strongly } \\
\text { agree }\end{array}$ \\
\hline $\begin{array}{l}\text { Q1: Peer review activities } \\
\text { using Google Docs were } \\
\text { difficult }\end{array}$ & 0 & $\begin{array}{c}8 \\
(42 \%)\end{array}$ & $\begin{array}{c}3 \\
(16 \%)\end{array}$ & $\begin{array}{c}7 \\
(37 \%)\end{array}$ & $\begin{array}{c}1 \\
(5 \%)\end{array}$ & 0 \\
\hline $\begin{array}{l}\text { Q2: If I had taken this } \\
\text { class face-to-face, it } \\
\text { would have been easier to }\end{array}$ & 0 & $\begin{array}{c}1 \\
(5 \%)\end{array}$ & $\begin{array}{c}1 \\
(5 \%)\end{array}$ & $\begin{array}{c}6 \\
(32 \%)\end{array}$ & $\begin{array}{c}7 \\
(37 \%)\end{array}$ & $\begin{array}{c}4 \\
(21 \%)\end{array}$ \\
\hline
\end{tabular}

The survey further asked the participants to choose the most challenging aspect of online peer reviews. Two out of 19 participants did not select any item, and one participant chose the item, none to show that they did not experience any difficulty. Six of the 19 participants (32\%) chose the items representing the theme of insufficient rapport building and another six participants selected the items regarding lack of skills (e.g. their ability to provide useful feedback in English). The other four participants reported technical problems, including Internet issues and difficulty using Google Docs.

After responding to the second question above, eighteen of the 19 participants responded to an open-ended question asking why they thought or did not think faceto-face peer review would have been easier than online peer review. Nine of the 18 comments mentioned communication difficulties participants had with the online peer review, such as not being able to communicate their opinions as smoothly as they would have been able to do if they were face-to-face. Six of the 18 comments indicated that the participants struggled with learning about their peers' personalities in an online situation, making it challenging to build rapport and provide feedback. This corresponds with Koh and Hill's (2009) findings that it sometimes requires more time to build rapport in online classes, and learners may experience difficulty understanding their classmates' personalities in an online learning environment. The remaining three participants wrote that they either thought that online peer review was similar to face-to-face peer review or preferred online peer review because they would have been more hesitant to give critical feedback in person.

\section{Efficacy}

This section addresses the third research question: to what extent did the participants find online peer review activities effective? Overall, the participants felt that online peer review had been effective in helping them to improve their written content, writing skills, and critical reading skills, as well as to review their grammar and learn about readers' perspectives.

While the degree of agreement differed, all 19 participants agreed that the online peer review activities were effective at helping them improve the written content of their book reports, their writing skills, and their critical reading skills (see Table 4). Eighteen of the 19 participants (95\%) found the online peer review effective at reviewing the grammar in their writing and learning about readers' perspectives. This may be partly because the focus of the peer review was more on global issues than local issues and partially because of the type of feedback they received from their peers. While this was not the main

Note. $\mathrm{N}=19$. 
focus of this study, analysis of the participants' feedback showed that some students provided more non-revision-oriented evaluative feedback such as "it sounds very interesting to me." Not receiving many revision-oriented comments might have caused some participants to view online peer reviews as ineffective for reviewing grammar or understanding the readers' viewpoints.

Table 4

Participant Answers Regarding the Efficacy of Online Peer Reviews

\begin{tabular}{|c|c|c|c|c|c|c|}
\hline Themes & $\begin{array}{l}\text { Strongly } \\
\text { disagree }\end{array}$ & Disagree & $\begin{array}{l}\text { Slightly } \\
\text { disagree }\end{array}$ & $\begin{array}{c}\text { Slightly } \\
\text { Agree }\end{array}$ & Agree & $\begin{array}{c}\text { Strongly } \\
\text { agree }\end{array}$ \\
\hline $\begin{array}{l}\text { Improving writing } \\
\text { content }\end{array}$ & 0 & 0 & 0 & $\begin{array}{c}2 \\
(11 \%)\end{array}$ & $\begin{array}{c}11 \\
(58 \%)\end{array}$ & $\begin{array}{c}6 \\
(32 \%)\end{array}$ \\
\hline Improving writing skills & 0 & 0 & 0 & $\begin{array}{c}3 \\
(16 \%)\end{array}$ & $\begin{array}{c}14 \\
(74 \%)\end{array}$ & $\begin{array}{c}2 \\
(11 \%)\end{array}$ \\
\hline $\begin{array}{l}\text { Improving critical reading } \\
\text { skills }\end{array}$ & 0 & 0 & 0 & $\begin{array}{c}10 \\
(53 \%)\end{array}$ & $\begin{array}{c}9 \\
(47 \%)\end{array}$ & 0 \\
\hline Reviewing grammar & 0 & 0 & $\begin{array}{c}1 \\
(5 \%)\end{array}$ & $\begin{array}{c}5 \\
(26 \%)\end{array}$ & $\begin{array}{c}9 \\
(47 \%)\end{array}$ & $\begin{array}{c}4 \\
(21 \%)\end{array}$ \\
\hline $\begin{array}{l}\text { Learning about readers' } \\
\text { perspectives }\end{array}$ & 0 & 0 & $\begin{array}{c}1 \\
(5 \%)\end{array}$ & $\begin{array}{c}6 \\
(32 \%)\end{array}$ & $\begin{array}{c}7 \\
(37 \%)\end{array}$ & $\begin{array}{c}5 \\
(26 \%)\end{array}$ \\
\hline
\end{tabular}

Note. $\mathrm{N}=19$.

In their comments, two participants stated that the online peer reviews helped them reflect on their strengths and weaknesses in their writing, which was also reported by Tsui and $\mathrm{Ng}(2000)$. Two other participants said they appreciated learning from their peers' writings, something also noted by Early and Saidy (2014). An interviewee supported this view and indicated that they became more aware of their own writing structures through comparing their writings with their classmates. In addition, two participants simply enjoyed the opportunity that the online peer review process provided them. In one participant's words, "even though it was through the screen, having opportunities to exchange our feedback was one of the things I was looking forward to during these gloomy days taking all the classes online."

\section{Discussion}

The results of the survey and interviews show that overall, the participants considered the online peer review effective even though it was conducted under unexpected circumstances. They thought that the online peer review helped them to improve their writing skills, the content of their compositions, and their critical reading skills. However, despite their generally positive feelings towards the online peer reviews, most participants indicated that the peer review would have been easier if it had been done in person and some participants reported that they faced challenges doing online peer reviews. Those difficulties stemmed from a lack of confidence in their skills, as well as from communication issues caused by the online nature of the peer-review process. Another difficulty they experienced was the lack of opportunities to get to know their peers online. Considering this challenge, it may have been beneficial to provide additional time for rapport-building activities before beginning the peer reviews, such as having the learners share information about themselves and their writing experiences. In addition, though previous research has reported the benefits of anonymous online peer review (e.g., Loretto et al., 2016), some learners indicated that they might prefer non-anonymous peer reviews when they have limited opportunities to interact with their classmates in person. On a similar note, some participants indicated that they appreciated the follow-up discussions in breakout rooms on Zoom, where they saw their classmates' faces as it helped them build rapport and negotiate the meaning of their feedback. This supports the idea that a combination of online written peer feedback and follow-up face-to-face discussions can help facilitate the effectiveness of online peer reviews (e.g., Li \& Li, 2018; Liu \& Sadler, 2003) even if the follow-up discussions are conducted online.

\section{Conclusion}

The findings of this study corroborate previous studies by showing that, overall, the online peer review was perceived positively by the participants. Most of the participants felt comfortable participating in the online peer review even without meeting their classmates in person, and they perceived it as an effective way to improve their writing and critical reading skills. This is important because how learners interpret classroom activities has been shown to influence the effectiveness of those activities, as well as the learners' motivation to engage in these activities (Loretto et al., 2016). However, this study also differs in several important ways from previous research. Although some studies have reported the effectiveness of anonymous peer review (e.g., Loretto et al., 
2016), some learners in this study communicated their preference for non-anonymous online peer review. Finally, this study also showed that spending extra time to build rapport may increase the effectiveness of online peer reviews.

To more accurately analyze the effect of online peer reviews, future research needs to examine the impact of online peer-review on learners' writing by examining how learners revised their writings. It would also be helpful to directly compare learners' experiences in face-to-face peer review with those of online peer reviews. In addition, there is a need to look more closely at the experiences of learners at different levels to maximize the effectiveness of online peer reviews for different groups of learners.

\section{Bio Data}

Shoko Kita teaches English at Rikkyo University in Tokyo. Her current research interests include teacher and learner creativity, critical thinking skills, and teacher development. <shoko.k.kita@gmail.com>

\section{References}

Chang, C. F. (2012). Peer review via three modes in an EFL writing course. Computers and Compositions, 29(1), 63-78. https://doi.org/10.1016/j.compcom.2012.01.001

Early, J. S., \& Saidy, C. (2014). Uncovering substance: Teaching revision in high school classrooms. Journal of Adolescent \& Adult Literacy, 58(3), 209-218. https://doi.org/10.1002/jaal.333

Guardado, M., \& Shi, L. (2007). ESL students' experiences of online peer feedback. Computers and Composition, 24(4), 443-461. https://doi.org/10.1016/j.compcom.2007.03.002

Ho, M.-C., \& Savignon, S. J. (2007). Face-to-face and computer-mediated peer review in EFL writing. CALICO Journal, 24(2), 269-290. Retrieved from https://www.jstor.org/stable/24147912

Koh, M. H., \& Hill, J. R. (2009). Student perceptions of group work in an online course: Benefits and challenges. Journal of Distance Education, 23(2), 69-92. Retrieved from http://www.ijede.ca/index. php/jde/article/view/477/904

Lee, L., \& Gundersen, E. (2011). Select readings: Teacher-approved readings for today's students (2nd ed.). Oxford University Press.

Li, J., \& Li, M. (2018). Turnitin and peer review in ESL academic writing classrooms. Language Learning \& Technology, 22(1), 27-41. https://doi.org/10125/44576

Liu, J., \& Sadler, R. W. (2003). The effect and affect of peer review in electronic versus traditional modes on L2 writing. Journal of English for Academic Purposes, 2(3), 193-227. https://doi.

org/10.1016/S1475-1585(03)00025-0
Lockhart, C., \& Ng, P. (1995). Analyzing talk in ESL peer response groups: Stances, functions, and content. Language Learning, 45(4), 605-655. https://doi.org/10.1111/j.1467-1770.1995 tb00456.x

Loretto, A., DeMartino, S., \& Godley, A. (2016). Secondary students' perceptions of peer review of writing. Research in the Teaching of English, 51(2), 134-161. Retrieved from https://www.jstor.org/ stable/24889912

Min, H.-T. (2006). The effects of trained peer review on EFL students' revision types and writing quality. Journal of Second Language Writing, 15(2), 118-141. https://doi.org/10.1016/j. jslw.2006.01.003

Moloudi, M. (2011). Online and face-to-face peer review: Measures of implementation in ESL writing classes. Asian EFL Journal, 52, 4-22. Retrieved from http://asian-efl-journal.com/PTA/ May-2011-Moloudi.pdf

Nelson, G. L., \& Murphy, J. M. (1993). Peer response groups: Do L2 writers use peer comments in revising their drafts? TESOL Quarterly, 27(1), 135-141. https://doi.org/10.2307/3586965

Saldaña, J. (2013). The coding manual for qualitative researchers (2nd ed.). Sage Publications.

Song, L., Singleton, E. S., Hill, J. R., \& Koh, M. H. (2004). Improving online learning: Student perceptions of useful and challenging characteristics. The Internet and Higher Education, 7(1), 5970. https://doi.org/10.1016/j.iheduc.2003.11.003

Tsui, A. B. M., \& Ng, M. (2000). Do secondary L2 writers benefit from peer comments? Journal of Second Language Writing, 9(2), 147-170. https://doi.org/10.1016/S1060-3743(00)00022-9

Wang, S., \& Usaha, S. (2009). How EFL university students use electronic peer response into revisions. Suranaree Journal of Science and Technology, 16(3), 263-275. Retrieved from https:// core.ac.uk/download/pdf/70937026.pdf

Zhao, H., Sullivan, K. P. H., \& Mellenius, I. (2014). Participation, interaction and social presence: An exploratory study of collaboration in online peer review groups. British Journal of Educational Technology, 45(5), 807-819. https://doi.org/10.1111/bjet.12094 
JALT2020

COMMUNITIES OF

\section{Appendix A}

\section{Survey Questions}

All the Likert-scale questions below provided six options: Strongly disagree, Disagree, Slightly disagree, Slightly agree, Agree, Strongly agree. In the actual survey, all questions were written in both English and Japanese.

1. Had you taken online courses before taking this R\&W course? Yes, No, Other

2. Likert-scale question: I felt worried about taking classes online before the semester.

3. Had you used Google Docs before you started taking the R\&W class? Yes, No, Other

4. If you said "yes" in the previous question (\#3), what did you use Google Docs for? Doing peer review in class, Taking notes, Writing a report, Other

5. Did you know any of your classmates before you joined the R\&W class? Yes, No, I was already friends with some classmates, Other

6. Likert-scale question: In this online R\&W class, I was able to build rapport with my classmates as much as I would have in a face-to-face class.

7. Likert-scale question: I was comfortable participating in peer review activities using Google Docs from the beginning.

8. Likert-scale question: I became more comfortable participating in the peer review activities on Google Docs as the semester went on

9. What helped you to feel more comfortable giving comments to your classmates' reports? Check as many as you like.

- Seeing each other in the online R\&W class every week

- Taking other English classes (e.g., Discussion class, e-Learning class) with the same classmates

- Taking other non-English classes together (your major etc.) online

- Talking to the classmates in pairs and groups in Zoom breakout rooms in the R\&W class

- Communicating with my classmates outside the class

- Feeling confident about my feedback points

- Feeling confident about my English skills

- Seeing how the instructor gave sample comments before doing peer reviews
- Having classmates who made me feel comfortable giving feedback

- Receiving instructions on how to give comments on Google Docs

- Practicing giving comments throughout the semester

- Seeing my classmates' comments

- Other

10. Likert-scale question: Peer review activities using Google Docs were difficult.

11. What made it difficult for you to participate in peer review activities using Google Docs? Choose top 3 reasons.

- Having insufficient time to see my classmates' face on Zoom

- Having insufficient opportunities to get to know my peer review partners

- Having Internet problems

- Being unsure about how to use Google Docs

- Not knowing what comments to give

- Having insufficient time to give comments

- Being unsure whether my suggestion was useful

- Not being confident about my English comments

- Not being confident about my critical reading skills

- None

- Other

12. If you chose "Other" in Question 11, please specify the content.

13. Likert-scale question: If I had taken this class face-to-face, it would have been easier to participate in peer review activities.

14. Please write reasons for your answer to Question \#13.

15. Likert-scale question: Peer review activities using Google Docs were useful to improve my reading skills.

16. Likert-scale question: Peer review activities using Google Docs were useful to improve my writing skills.

17. Likert-scale question: Peer review activities using Google Docs were useful to improve skills to read critically.

18. Likert-scale question: Peer review activities using Google Docs were useful to understand readers' viewpoints. 


\section{JALT2020}

COMMUNITIES OF
19. Likert-scale question: Peer review activities using Google Docs were useful to understand which parts of my writing may be unclear to readers.

20. Likert-scale question: Peer review activities using Google Docs were useful to think about grammar points.

21. Likert-scale question: Peer review activities using Google Docs were useful to improve contents in my writing.

22. If you remember things you learned from your classmates' comments, please write anything (content, ideas, grammar, vocabulary etc.) here.

23. If there are things that could have made your peer review experience better, please write your ideas.

24. Please write your thoughts on the peer review activities using Google Docs.

\section{Interview Questions}

\section{Appendix B}

The actual interview questions had Japanese translations and the questions were asked in Japanese in the interview sessions.

1. When you gave feedback to your peers on Google Docs, how comfortable were you to point out your peers' errors or unclear parts? Why?

2. How comfortable were you when you received feedback from your peers on Google Docs about your errors or unclear parts? Why?

3. How honest were you when you gave feedback to your peers on Google Docs?

4. Do you think anonymous feedback would have been easier for you to give feedback to your partners online?

5. Do you think anonymous feedback would have been easier for you to receive feedback online?

6. We had one to two reviewers in each peer review activity. Was the number of reviewers appropriate for you? If you would like more peers or fewer peers, please tell me with reasons.

7. Do you think having some "get to know" time (for example in a warm-up activity) in breakout rooms before peer reviewing would have helped you feel more comfortable doing the peer review activities? Please see the examples below.
Example questions for a "get to know your peer" activity

1. Tell me about one thing you enjoy in your free time.

2. What topic did you choose for this assignment? Why?

3. What do you think you did well in this assignment?

4. What was challenging for you when you worked on this assignment?

5. What would you like me to focus on when I read your writing? Why? 